\title{
Sosiale ulikheter i barnedødelighet
}

\section{De sosiale forskjellene i barne- dødelighet er minst i ukene rundt termindato og i barnets første leveuke. Dette er den perioden da mor og barn har mest kontakt med helsevesenet.}

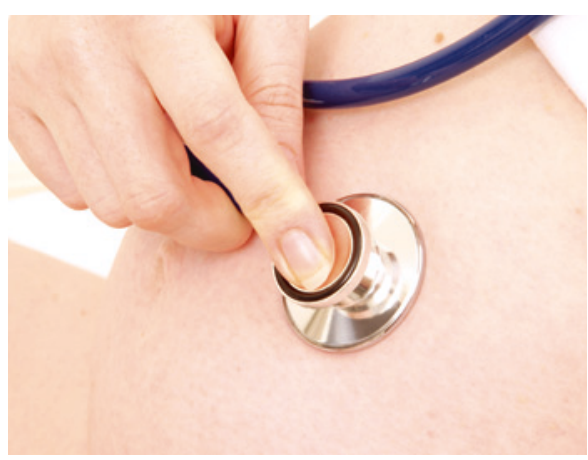

Illustrasjonsfoto Istockphoto
Svangerskapskontrollene er hyppigst i ukene rundt terminen, og nybakte mødre får tett oppfølging fra barselavdeling og helsestasjon uken etter fødselen. I en studie vi nylig har publisert i European Journal of Public Health fant vi at dette er den perioden da de sosiale forskjellene i barnedødelighet er minst (1). Studien omfattet alle barn av norske mødre i perioden 1999-2005. For svangerskapsuke 16-36 var fosterdødeligheten hos kvinner med kun grunnskoleutdanning $80 \%$ høyere enn hos kvinner med universitetsutdanning. Barnedødeligheten i tiden etter første leveuke og opp til ettårsalderen var $120 \%$ høyere i den førstnevnte gruppen.

I perioden 1967-2005 var det $80 \%$ nedgang i perinatal død i Norge. Dette tilsvarer ca. 16000 barn. Nedgangen var størst for gutter (2). Nedgangen i barnedødelighet kan tilskrives sosial og geografisk utlikning i tilgang på effektiv helsetjeneste. Hyppige rutinekontroller og introduksjon av ny teknologi i svangerskaps- og fødselsomsorgen bidrar til objektiv diagnostisering uavhengig av sosial status. Etter 2005 er det imidlertid blitt færre kontroller i svangerskapet, og barselomsorgen er bygd ned. Dette kan få betydning for den sosiale ulikheten i barnedødelighet.

\section{Anne Eskild \\ anne.eskild@medisin.uio.no \\ Jostein Grytten \\ Universitetet i Oslo \\ Litteratur \\ Carlsen F, Grytten J, Eskild A Maternal education and risk of offspring death; changing patterns from 16 weeks of gestation until one year after birth. Eur J Publ Health 2013. http://eurpub. oxfordjournals.org/content/early/2013/06/19/ eurpub.ckt065.full.pdf?keytype $=$ ref\&ijkey= cPzCPBLGp9BTD54 (20.6.2013) \\ 2. Carlsen F, Grytten J, Eskild A. Changes in fetal and neonatal mortality during 40 years by offspring sex: a national registry-based study in Norway. BMC Pregnancy Childbirth 2013; 13: 101.}

\section{Er musemodeller pålitelige kunnskapskilder?}

\section{Gentranskripsjonen ved inflammasjonsprosesser hos mennesker og i musemodeller er ikke lik.}

Musemodeller brukes hyppig ved forskning på humane sykdommer, både for å kartlegge sykdomsmekanismer og for utprøvning av nye medikamenter. Svært ofte viser det seg at funn fra musemodeller ikke kan overføres til mennesker. Overføringsverdien har vært særlig dårlig når det gjelder forsøk på å blokkere inflammasjonsresponsen hos kritisk syke pasienter.

Nå foreligger det data fra en stor studie der genekspresjonsprofilen til leukocytter fra mennesker og mus ved sepsis, traumer, brannskader og endotoksemi er sammenliknet (1). Hos mennesker liknet transkripsjonsresponsene ved disse tilstandene hverandre, mens responsen i musemodellene avvek betydelig fra responsen hos mennesker.

- Forsøksmus har i lang tid vært en svært viktig kilde til kunnskap om humane sykdommer, sier avdelingsleder Harald Carlsen, Avdeling for komparativ medisin, Institutt for medisinske basalfag, Universitetet $i$ Oslo. - Slik vil det også være i mange år fremover. Samtidig må vi erkjenne utfordringene vi har når vi velger dyremodeller. gjør, sier han. relevante, sier Carlsen.

\section{Haakon B. Benestad}

h.b.benestad@medisin.uio.no

Universitetet i Oslo
Denne studien er interessant, men kanskje noe misvisende. Den viser hvordan store ulikheter mellom klassiske inflammasjonssituasjoner hos mennesker og hos mus kan gi misvisende resultater dersom man ikke tar hensyn til dem. Særlig gjelder dette følsomhet overfor inflammasjonsstimuli, i dette tilfellet bl.a. bakterielt endotoksin, som mennesker tåler mye mindre av enn mus

- For å få vite hva som foregår i menneskekroppen, kommer vi ikke utenom forsøksdyr når vi vil se inn $\mathrm{i}$ celler og organer og forstå biologiske mekanismer. Vi må velge dyremodeller med omhu for å finne de mest

\footnotetext{
Litteratur

1. Seok J, Warren HS, Cuenca AG et al. Genomic responses in mouse models poorly mimic human inflammatory diseases. Proc Natl Acad Sci USA 2013; 110: 3507-12.
}

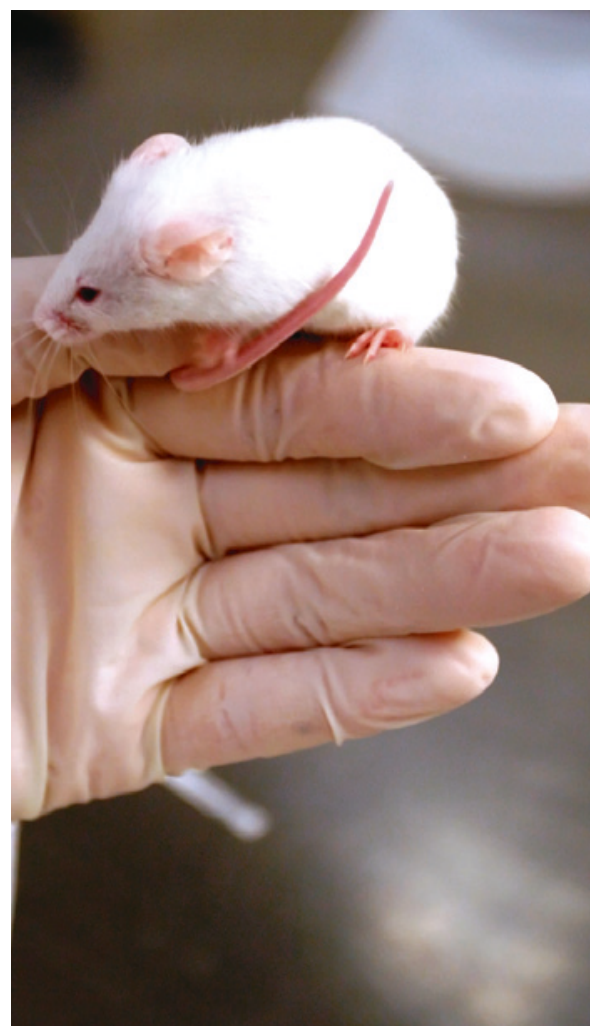

Illustrasjonsfoto Istockphoto 